\title{
INVESTIGATION OF THE ASEXUAL REPRODUCTIVE CHARACTERISTICS OF NATIVE SPECIES FOR SOIL BIOENGINEERING IN THE WEST INDIES
}

\author{
Mira $\mathbf{E}^{1,2, *}$, Evette $\mathbf{A}^{2}$, Labbouz $\mathbf{L}^{3}$, Robert $\mathbf{M}^{3}$, Rousteau $\mathbf{A}^{4} \&$ Tournebize $\mathbf{R}^{1}$ \\ ${ }^{1}$ INRAE, UR ASTRO, 97170 Petit-Bourg, Guadeloupe, France \\ ${ }^{2}$ Univ. Grenoble Alpes, INRAE, LESSEM, F-38402 St-Martin-d'Hères, France \\ ${ }^{3}$ Parc national de la Guadeloupe, Habitation Beausoleil, Montéran 97120 Saint-Claude Guadeloupe FWI \\ ${ }^{4}$ UA, UMR EcoFoG, CNRS, Cirad, INRAE, Université des Antilles, Université de Guyane, Université des Antilles, 97159 \\ Pointe-à-Pitre, France \\ *eleonore.mira@inrae.fr
}

Submitted June 2020; accepted December 2020

\begin{abstract}
Erosion and landslides are frequent disasters in the Caribbean. The stabilisation of watercourses banks and the slopes of gullies are necessary to prevent erosion. Soil bioengineering offers more environmentally respectful solutions than traditional civil-engineering techniques in order to prevent soil erosion. Soil bioengineering includes vegetation as a building material. These techniques are not very widespread in the Caribbean and therefore basic research is necessary. Vegetative propagation is a low-cost, fast and effective way to obtain plant material. The development of soil bioengineering techniques also involves controlling species vegetative propagation. Appropriate species identification was conducted through literature review on the rooting ability of plant cuttings involving 31 Caribbean native herbaceous, shrubs and tree species adapted to riparian conditions. An ex situ study was carried out to evaluate the vegetative propagation potential of cuttings in the context of soil bioengineering development. Our results indicated that some native Caribbean species could be easily propagated through cuttings. Among the selected species; three trees, five shrubs and three herbaceous species were found to be easily adapted to the controlled propagation in low-tech conditions. It is consistent and suitable with soil bioengineering techniques in the Caribbean.
\end{abstract}

Keyword: Soil bioengineering, nature-based solutions, erosion, tropical riparian ecosystems, cuttings, Caribbean, Protéger project

\section{INTRODUCTION}

The stabilisation work to protect banks of watercourses and the slopes of gullies is the responsibility of local authorities to prevent erosion and to guarantee the safety of the public. In most stabilisation efforts, these construction works use civil engineering techniques, mostly involving rocks or concrete ripraps. Although these widely used civil engineering techniques are mechanically efficient, they have significant negative impacts on the ecological structures and functions in riparian ecosystems by degrading riparian and aquatic biodiversity, buffer zones and ecological corridors (Cavaillé et al. 2015, Schmitt et al. 2018, Janssen et al. 2019).

Soil bioengineering represents a better option as compared to civil engineering with respect to both environmental and landscape perspectives. Soil bioengineering is a nature-based solution to the societal challenge of disaster risk protection, whose implementation imitates natural plant settings in the communities (Cohen-Shacham et al. 2016). Soil bioengineering can be defined as the inclusion of vegetation into engineering designs to improve and protect slopes, embankments and structures from problems associated with erosion and other types of shallow slope failures (Clark \& Hellin 1996). A distinct characteristic of soil bioengineering is plants or plant materials are used to build living structures that can stand alone or work in combination with other inert materials (Schiechtl \& Stern 1996, Adam et al. 2008), where the vegetation itself provides mechanical functions such as anchoring for stability.

Erosion is common in the humid tropic due to high rainfall events and sometimes associated with frequent hurricanes. More than $40 \%$ of the precipitation events have an intensity greater 
than $25 \mathrm{~mm}$ per hour as compared with less than $5 \%$ in non-tropical zones and intensities above $150 \mathrm{~mm}$ per hour are very common (Díaz 2001). On the steep slopes geologically related to young volcanic edifices, even minor disturbances can induce erosion and landslides. The costs associated with these hazards are considerable and soil bioengineering is therefore a feasible, economical and ecologically friendly alternative for erosion control (Clark \& Hellin 1996) even if pure civil engineering method is available.

The Greater and Lesser Antilles constitute the Caribbean Island hotspot, where it is one of the 34 world biodiversity hotspots. The local flora and fauna are both rich and threatened, with a high level of endemism (Myers et al. 2000). The Guadeloupe Archipelago shows a remarkable biodiversity among its islands and the terrestrial vegetation contains 1706 native species (IUCN 2019) hidden in 34 types of ecosystems (Rousteau et al. 1996). In the context of global climate change and the run-away erosion affecting the biodiversity, conserving and restoring degraded ecosystems, particularly those under anthropogenic pressure such as riparian areas has become a priority. Soil bioengineering techniques can be an efficient tool to overcome biotic factor such as invasive species or abiotic factor such as severe erosion damage and to reestablish successional trajectories of the ecosystem (Polster 2016). The rich indigenous species provide the source of finding suitable flora for the development of soil bioengineering techniques.

The Lesser Antilles is well known for its flora diversity but their riparian assemblages remain poorly identified. The main plant species used in the few existing soil bioengineering projects are mostly exotic, even though some native species have been identified as suitable (Clark \& Hellin 1996, Díaz 2001). The first study on characterising these plant communities in Guadeloupe was conducted by Gayot et al. (2018). It proposes an operational typology composed of twelve distinct riparian plant community types, influenced by four main covariables such as rainfall, altitude, salinity and river slope. Among the species observed, 80 species of trees, shrubs and herbaceous plants in different riparian ecosystems have been identified as potentially useful in soil bioengineering.

The selected plant species must present a compatible set of biotechnical traits considered to be suitable for soil bioengineering usage.
The plants must be ruderal pioneer species with strongly developed roots, high growth rate for both aerial and root components and quick to regenerate after disturbance. Other required characteristics are high immersion and burial tolerance, drought resistance and good nitrogen fixation to improve soils. The selected plants must be easily propagated and able to produce many seeds or vegetative materials for mass cultivation and acceptable by the local communities (Clark \& Hellin 1996, Díaz 2001, Norris et al. 2008).

The initial step in using indigenous species for soil bioengineering in the Caribbean is to control asexual propagation especially through cutting method. Vegetative reproduction through cuttings is a low-cost, fast and effective way to obtain important woody plant material for the basic soil bioengineering techniques for live fascines, brush mattresses, brush layers or live stakings (Clark \& Hellin 1996, Zeh 2007).

Little information is available from the literature search on the rooting ability of cuttings from Caribbean native species. However, the natural ability for some cuttings to resprout has been described for certain tropical species (Hallé 2005, Bellefontaine 2018), including those of the riverine ecosystems (Rood et al. 2003, Kontoh 2016). Asexual propagation of tropical riparian trees and shrubs is a widely used strategy in response to the frequent flood disturbances in their respective environments (Nakamura \& Inahara 2007). The hypothesis for this study is that a large number of Guadeloupian riparian species are able to resprout through cuttings and will therefore potentially be useful in soil bioengineering. Among the 80 Caribbean riverine species proposed by Gayot et al. (2018), 31 of the most promising native species are selected in order to make an extensive bibliographical review and to evaluate the few replicates per species related to their cutting propagation potential in the cost-constrained conditions for soil bioengineering projects.

\section{MATERIALS AND METHODS}

\section{Bibliographic review}

Literature review was conducted by Google Scholar search engine in 2019 and included studies published in peer reviewed journals, books, papers in conference proceedings and technical reports. The keywords used were 'propagation' or 'cuttings' or 'vegetative 
multiplication' associated with each species name and their taxonomic synonym, following the Tropicos 2019 database. Works in French, Spanish, English and Portuguese were retrieved and screened for relevance. The extracted information from these publications were summarised according to the plant parts related to cutting experiment, experimental conditions and the vegetative propagation tests.

\section{Species selection and sampling}

The 31 native riparian species consisting of 5 herbaceous plants, 6 shrubs and 20 trees were selected according a multi-criteria analysis including traits useful for bioengineering such as pioneer ecological status, resistance to disturbance, propagation potential, ability to fix nitrogen and growth form.

Plant cuttings were collected during the rainy season in July 2019. The collection site was located at a riparian area on the Basse-Terre Island (Figure 1) with the altitude between 0 and $300 \mathrm{~m}$ above sea level. For tree sample, one branch with minimum diameter of $2.5 \mathrm{~cm}$ was collected from four different individuals per species. Branch cuttings with the leaves removed were prepared in similar length of 60 $\mathrm{cm}$. For shrub and herbaceous plant sample, segments with at least four nodes were collected from four different individuals per species. Special collection for the vegetative bulbils of Thelypteris reticulata and the shoots on the long internodes of Ischnosiphon arouma was carried out as these were the special plant parts for asexual propagation (Howard 1977, Cremers 1992). The cuttings were stored at ambient temperature in the shade and planted within 24 hours after sampling.

\section{Experimental conditions}

Experimental conditions such as light intensity and daily precipitation were considered as representative to possible natural conditions at the site of bioengineering works. Complex and costly laboratory techniques to produce the plant materials were avoided and performed under a simple shade house (Figure 2). The rooting rates of plant cuttings were negatively affected by light intensity (Loach \& Gay 1979, Grange \& Loach 1985), thus for light intensity test, the plants were protected from light stress under a shade house with $60 \%$ light reduction. For the test corresponding to daily precipitation, the cuttings were planted in $70 \mathrm{~L}$ containers filled with a mixture of river sand and natural soil with the ratio of 3:1 within 24 hours of sampling. Two third of the length for each cutting was buried and left in the containers for

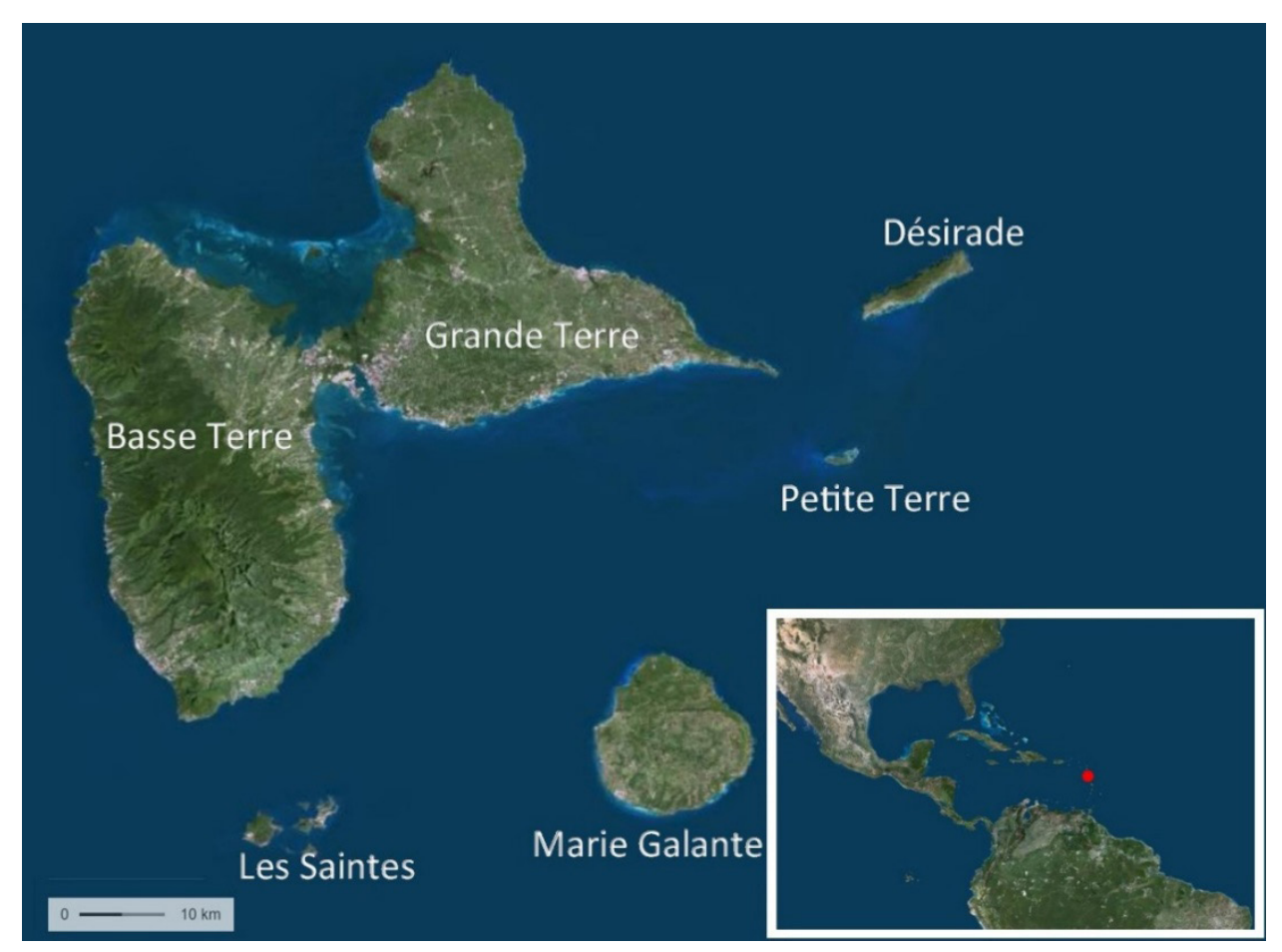

Figure 1 Geographical location of the Guadeloupe Archipelago (Geoportail 2019) 


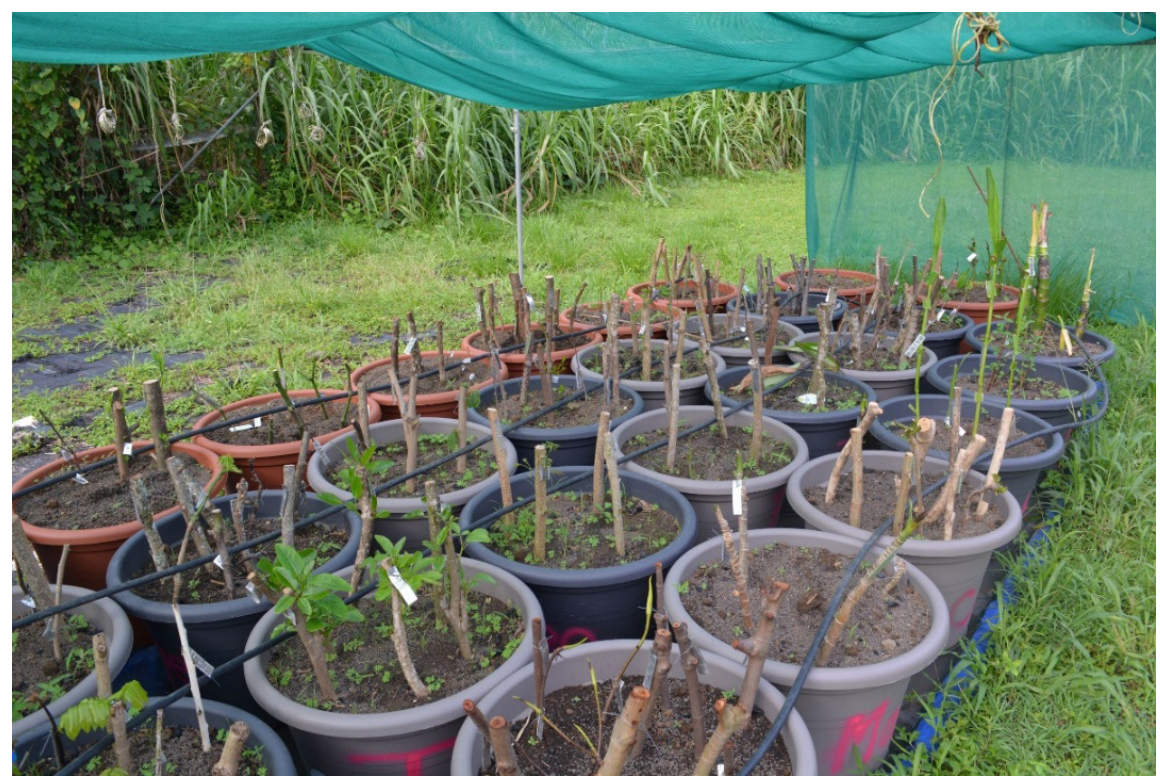

Figure 2 Shade house installation of the cutting experiment

three months for woody species and three weeks for the faster growing non-woody species.

\section{RESULTS}

Among the 31 selected species from the literature review, focus was given to 13 species consisted of 10 trees, 2 shrubs and 1 herbaceous plant cuttings based on their rooting ability (Table 1). In the literature survey on various past studies, less than $10 \%$ of the experiments were conducted in natural conditions. Most of the methods in the studies were by in vitro propagation, under propagation bell or used of hormones to enhance the rooting potential of the plant material. Different plant parts were used in these experiments, where more than $90 \%$ were stems. Among the 13 species previously tested and reported in the literature, stem cuttings from 11 species were able to resprout.

Plant cuttings from 25 species started to produce leaves a few days after planting (Figure $3)$. However, among the 31 species tested, only 11 species cuttings showed $25 \%$ to $100 \%$ producing roots. They consisted of three trees, five shrubs and three herbaceous plants (Table 2, Figure 4). The resprouting species showed a diversity of ecological features and belonged to all forest ecosystem types. The number of successfully rooting species showed that ten of the eleven successful species belonged to the seasonal evergreen forest type whereas only one was found in the coastal forest. Among the successful species, three species were identified as helophytes; Dieffenbachia seguine and Hymenachne amplexicaulis were herbaceous and Ludwigia hyssopifolia was a shrub. Some of the other successful species covered wide ecological range, where Homalium racemosum and Piper dilatatum, were commonly found from dry forest to rainforest and Citharexylum spinosum only be found in dry forest.

\section{DISCUSSION}

The review of the available literature concerning the asexual propagation potential of native Caribbean riparian species used in bioengineering projects was not sufficient and could be improved. The bibliographic data concerning the selected species were sometimes very old (Noisette 1826, Jacques et al. 1847) and the methods employed to obtain plants from cuttings such as leaf cutting propagation or in-vitro propagation were often unsuitable with the conditions required for bioengineering techniques (Thirunavoukkarasu et al. 2004, Deccetti et al. 2005).

In the experiment, $60 \%$ of the selected herbaceous plants and $83 \%$ of the selected shrubs resprouted from cuttings, whereas only $15 \%$ of the selected tree species rooted. Asexual propagation helped ground level plants of smaller size such as the shrubs and herbaceous to compensate for their vulnerability 


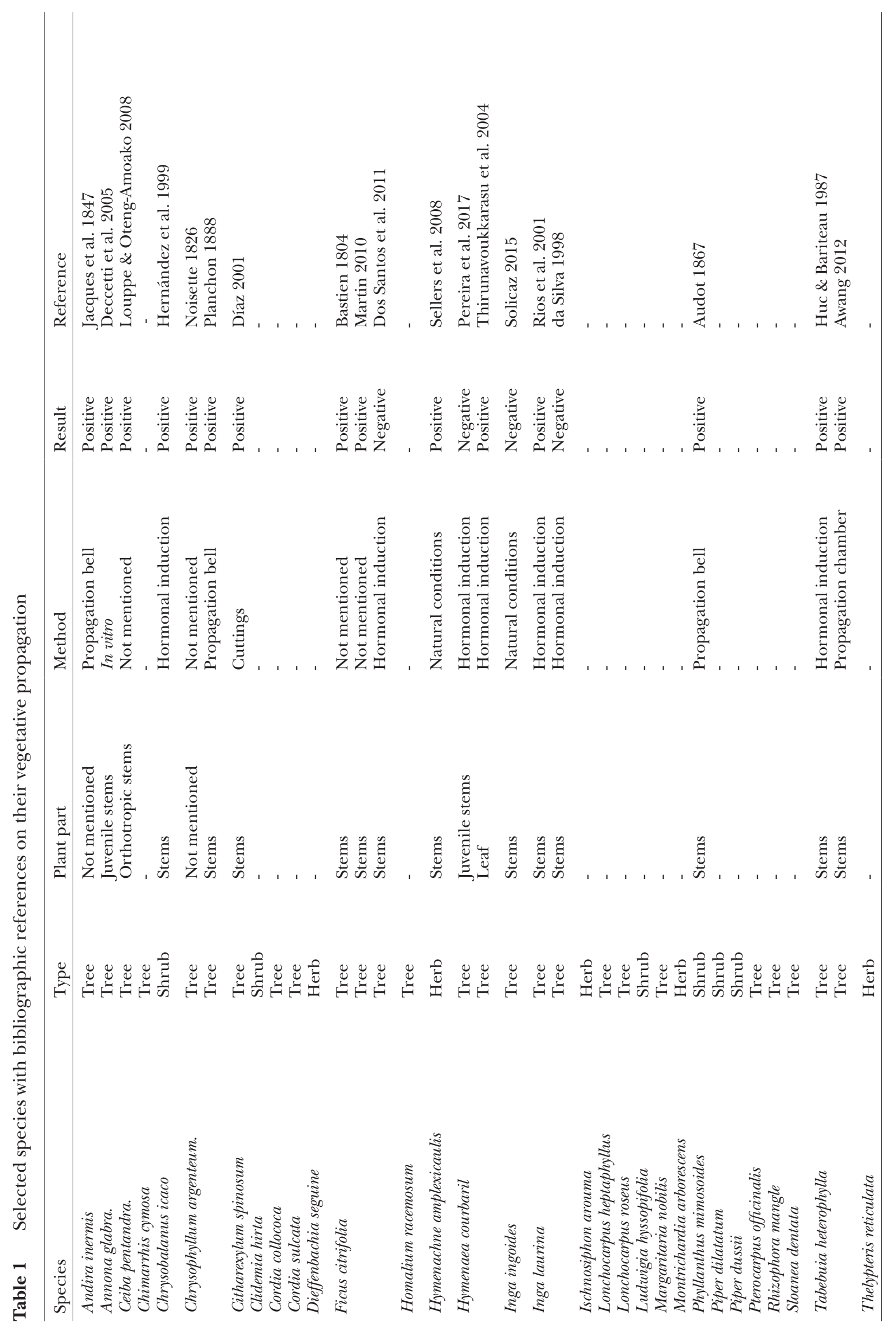



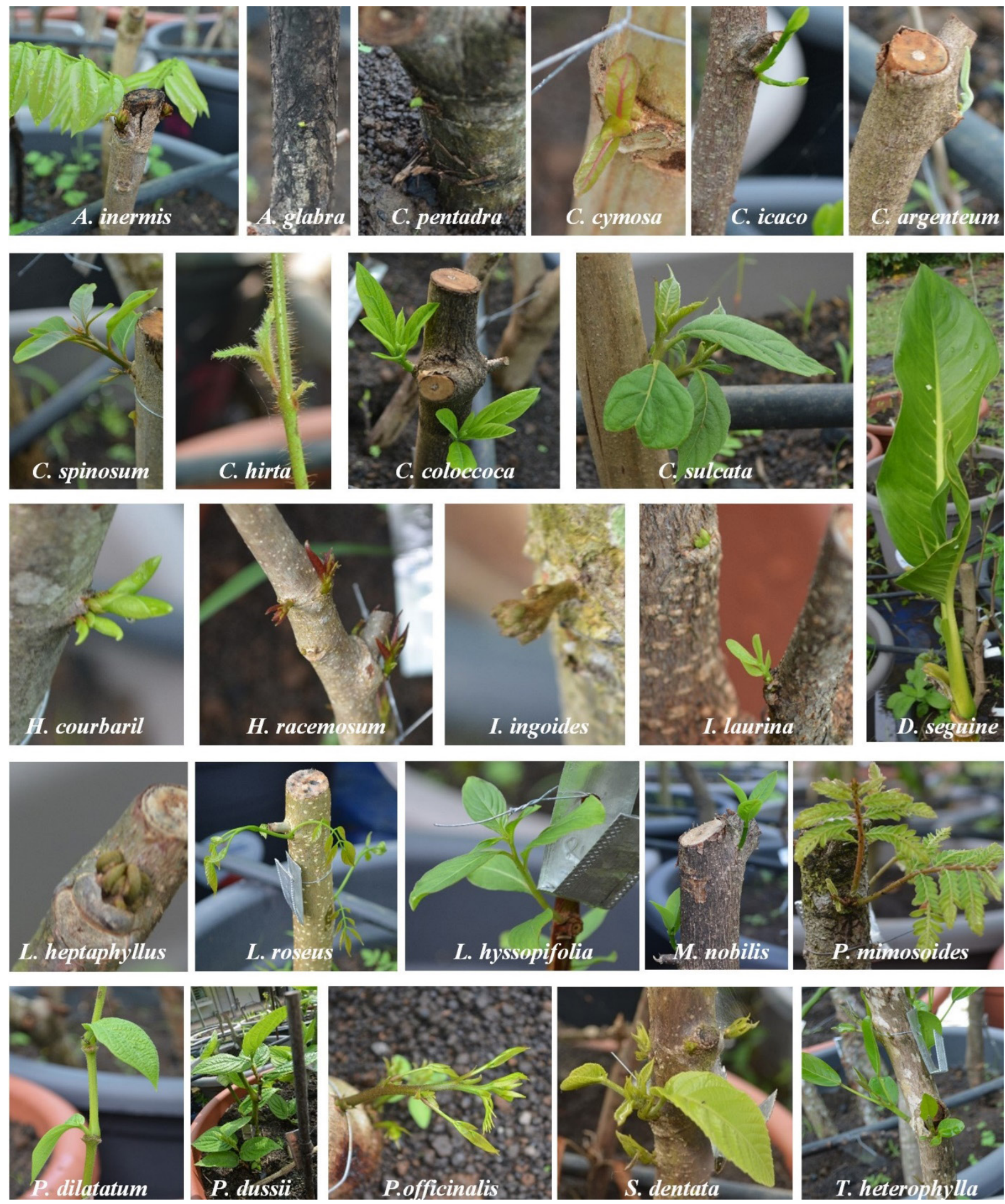

Figure 3 Leaf production on cuttings of selected species

to frequent disturbance by a high resprouting ability, whereas trees avoided many disturbances because of the tall and hardy nature (Vesk 2006). The selected herbaceous and shrub species easily colonise highly degraded or frequently disturbed areas (Fournet 2002) due to their natural vegetative propagation abilities. The findings may contribute to the successful strategy contributing to the establishment and fast development in areas where unavoidable disturbances of soil often cause the loss of most above-ground biomass.

The results obtained are consistent with the hypothesis of a high vegetative multiplication ability in Caribbean riparian plant communities as seen in the cuttings of the herbaceous plants 
Table 2 Percentage of rooted cuttings for the 11 successful selected species

\begin{tabular}{|c|c|c|c|c|c|c|c|c|}
\hline Species & $\begin{array}{c}\text { Rooted } \\
\text { cuttings }(\%)\end{array}$ & $\begin{array}{c}\text { Mean height } \\
(\mathrm{m})\end{array}$ & Helophyte & $\mathrm{S}$ & $\mathrm{C}$ & $\mathrm{D}$ & SE & $\mathrm{R}$ \\
\hline Chimarrhis cymosa & 50 & 15 & - & - & - & - & $\mathrm{x}$ & $\mathrm{x}$ \\
\hline Citharexylum spinosum & 50 & 8 & - & - & - & $\mathrm{x}$ & - & - \\
\hline Clidemia hirta & 100 & 1 & - & - & - & - & $\mathrm{x}$ & $\mathrm{x}$ \\
\hline Dieffenbachia seguine & 100 & 1.5 & $\mathrm{x}$ & $\mathrm{x}$ & $\mathrm{x}$ & - & $\mathrm{x}$ & - \\
\hline Homalium racemosum & 50 & 15 & - & - & - & $\mathrm{x}$ & $\mathrm{x}$ & $\mathrm{x}$ \\
\hline Hymenachne amplexicaulis & 100 & 1.5 & $\mathrm{x}$ & $\mathrm{x}$ & - & - & $\mathrm{x}$ & - \\
\hline Ludwigia hyssopifolia & 100 & 1.5 & $\mathrm{x}$ & $\mathrm{x}$ & - & - & $\mathrm{x}$ & - \\
\hline Piper dilatatum & 25 & 2 & - & - & - & $\mathrm{x}$ & $\mathrm{x}$ & $\mathrm{x}$ \\
\hline Piper dussii & 50 & 2 & - & - & - & - & $\mathrm{x}$ & $\mathrm{x}$ \\
\hline Phyllanthus mimosoides. & 25 & 1.5 & - & $\mathrm{x}$ & - & - & $\mathrm{x}$ & $\mathrm{x}$ \\
\hline Thelypteris reticulata & 75 & 1 & - & - & - & - & $\mathrm{x}$ & $\mathrm{x}$ \\
\hline
\end{tabular}

$\mathrm{S}=$ swamp forest, $\mathrm{C}=$ coastal forest, $\mathrm{D}=$ dry forest, $\mathrm{SE}=$ seasonal evergreen forest, $\mathrm{R}$ = rainforest

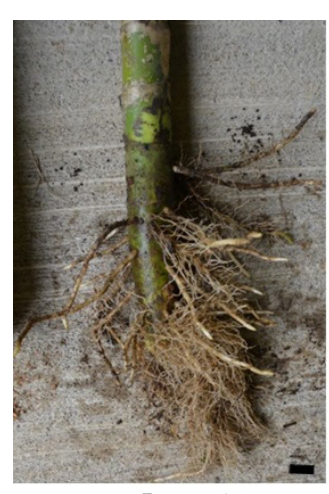

D. seguine

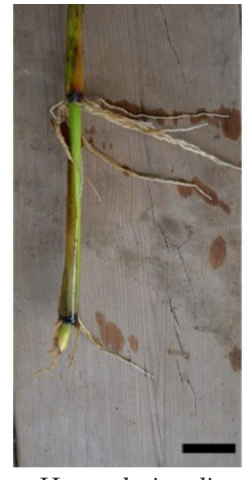

H. amplexicaulis

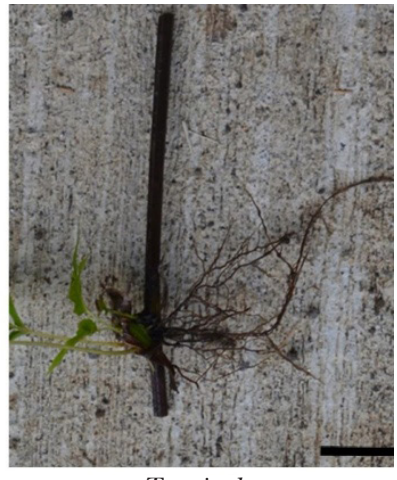

T. reticulata
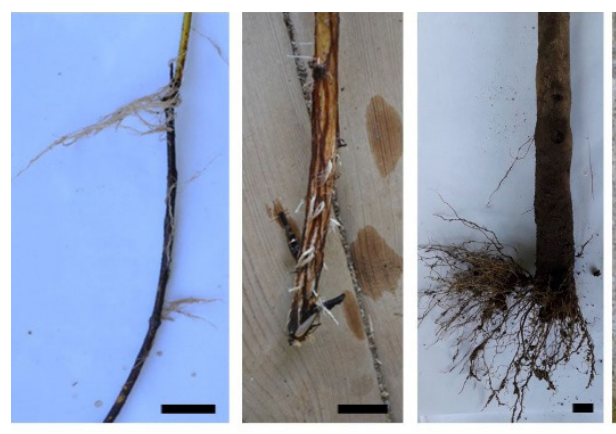

P. mimosoides

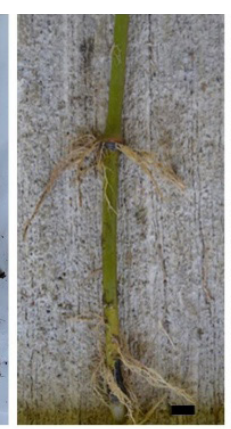

P. dilatatum

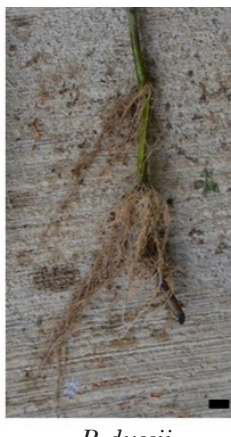

P. dussii

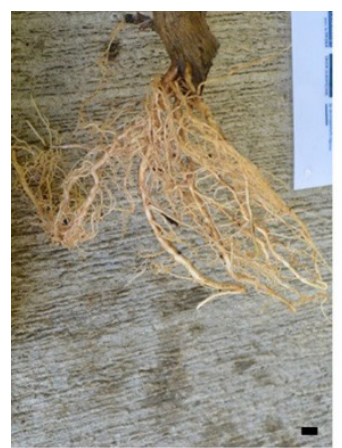

C. spinosum

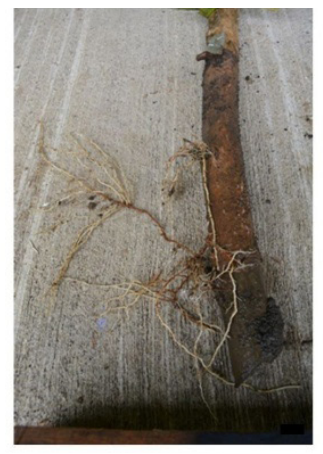

C. cymosa

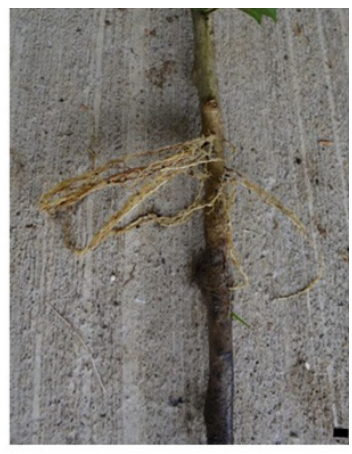

H. racemosum

Figure 4 Root system of resprouting cuttings. Photographs were taken 3 months after plantation for D. seguine, P. mimosoides, P. dilatatum, P. dussii, T. reticulata, C. spinosum and C. cymosa and 3 weeks after plantation for C. hirta, L. hyssopifolia and H. amplexicaulis and bars represent a $1 \mathrm{~cm}$ scale 
and shrubs. The findings also showed that native species such as helophytes can be integrated into soil bioengineering structures and fascines.

Many tests involving tropical forest tree species cuttings have been successfully conducted (Amri 2010, Bellefontaine 2018), including trees from the Caribbean (Lilin \& Koohafkan 1987). However. some genera from the present study like Ficus sp or Inga sp are known for their limited ability to root from cuttings (da Silva 1998, Danthu et al. 2002). Propagating woody species from cuttings or plantings is particularly challenging for soil bioengineering in Guadeloupe, due to the preserved riverine ecosystems mostly support only riparian forests. In the natural succession of a riparian ecosystems, the first stage often involves fast-growing pioneer trees closing the canopy. Tree species drive the entire structure and evolution of riparian forests and further investigation is needed to provide more options for multiplying these crucial components of the ecosystem. Thus, in current soil bioengineering practices, cuttings from shrub and tree species are key elements for area establishment (Clark \& Hellin 1996, Díaz 2001). The ability to grow more variety of plant species from cuttings would add additional benefit to the surroundings in Guadeloupe, considering its large diversity of biotic and abiotic conditions.

The poor resprouting rate of trees cuttings in the study could possibly be explained by the signs of rot at the base of some of the cuttings, suggesting water excess that may have impeded gaseous exchange at the site of root initiation. However, the experiment managed to identify species which are able to root easily in moist soils like the natural conditions along riverbanks. Various parameters may influence the rooting success of cuttings of tropical woody species. They are the nature of the species, the abiotic conditions like substrate, watering, temperature and air humidity, the position from which the cutting is taken on the tree, the age of the cutting, the sampling season of the cuttings, the application of incisions, the duration between harvesting and planting, the maintenance of leaves and the use of hormones (Bellefontaine 2018). However, the use of hormones could be relevant to increase the rate of rooting success in the cuttings of the selected species. The role of auxins, in particular indole-3-butyric acid (IBA) in the promoting root emission has been established in tropical trees cuttings (Teklehaimanot et al. 2004, Amri 2009). IBA influences polysaccharide hydrolysis which induces an increase in the content of physiologically active sugar. These sugars feed meristematic tissues and contribute to root primordia and root formation (Husen \& Pal 2007, Amri et al. 2010). Even though an IBA treatment on cuttings before the installation procedure would undoubtedly impact the cost of the bioengineering project, it may still remain feasible and applicable in field conditions. The application of IBA to the species that showed poor resprouting will be the future testing to determine the practicality of using cuttings and the 20 species that were unable to resprout from cuttings will be tested for seed germination potential in future experiments.

The present study was conducted over a short three-month period whereas the decisive survival of cuttings can only be assessed after approximately three years in temperate environments (Rey \& Burylo 2014). Even though the current experiment was carried out at a shorter period, the findings remain relevant as the non-sprouting species were separated and leaving only the quick resprouting species which are essential in soil bioengineering to stabilize the soil soon as possible to avoid further soil disturbance. These preliminary results are very important to the local authorities and researchers who previously faced lack of information about the resprouting ability of cuttings from the Guadeloupian indigenous species. Presently, local authorities use mostly exotic species such as Gliricidia sepium or Chrysopogon zizanioides which function as invasive species and become a treat to the rich and endangered flora of Caribbean.

The experimental results and the related bibliographical reviews opened new innovative ways for practitioners and researchers on the use of local flora for soil bioengineering in the Caribbean. Other relevant conditions in the context of soil bioengineering such as the flexural behavior, pull out resistance and tolerance to submersion can be included for further studies (Saifuddin \& Normaniza 2016, Leung et al. 2018).

\section{CONCLUSIONS}

Some native Caribbean riparian species have the potential to be used in the development of soil bioengineering. Among the 31 selected species, 
the asexual propagation of three herbaceous plants, five shrubs and three tree species were compatible with the cost constraint works of soil bioengineering projects. This preliminary study conducted over a short period provided valuable results for forthcoming scientific tests and applied works. Further investigation concerning both asexual and sexual propagation of riparian species is expected and best planned to enhance the development of soil bioengineering with native species not only in Guadeloupe but also in the Caribbean.

\section{Acknowledgements}

The study was conducted under the Protéger project with the funding from the European Union European Regional Development Fund, the French Agency for Biodiversity, the National Park of Guadeloupe, the French National Institute for Agriculture, Food and Environment and the University of Antilles.

\section{REFERENGES}

AdAm P, Debiais N, Gerber F et AL. 2008. Le génie végétal, un manuel technique au service de l'aménagement et de la restauration des milieux aquatiques. Ministère de l'écologie, du développement et de l'aménagement durables, Paris.

Amri E, Lyaruu HVM, Nyomora AS et al. 2009. Evaluation of provenances and rooting media for rooting ability of African Blackwood (Dalbergia melanoxylon Guill. E Perr.) stem cuttings. Research Journal of Agriculture and Biological Sciences 5: 524-532. doi: 10.1007/s11056009-9163-6

Amri E, Lyaruu HVM, Nyomora AS et al. 2010. Vegetative propagation of African Blackwood (Dalbergia melanoxylon Guill. $\mathcal{E}$ Perr.): effects of age of donor plant, IBA treatment and cutting position on rooting ability of stem cuttings. New Forests 39: 183-194. doi: 10.1007/s11056-009-9163-6

Audot 1867. Revue Horticole, année 1867. Hortalia, Paris.

AwANG Y. 2012. Effect of ontogenic age on root and shoot development of Tabebuia heterophylla cuttings propagated in soilless culture. African Journal of Agricultural Research. 6: 5422-5427 doi: 10.5897/ AJAR09.597

BASTIEN JF. 1804. La nouvelle maison rustique, ou économie rurale, pratique et générale de tous les biens de campagne. Deterville, Paris.

Bellefontaine R. 2018. La régénération par graines et par multiplication végétative à faible coût (drageons et boutures de segments de racine). CIRAD, Montpellier.

Clark J \& Hellin J. 1996. Bio-engineering for Effective Road Maintenance in the Caribbean. Natural Resources Institute, Chatham, UK.

Cohen-Shacham E, Walters G, Janzen C et al. 2016. Nature based solutions to address global societal challenges. IUCN. Switzerland. doi: 10.2305/IUCN.CH.2016.13.en
CREMERS G. 1992. L'architecture Des Marantaceae en Guyane Française. Bulletin de la Société Botanique de France. 139: 141-154. doi: 10.1080/01811797.1992.10824950

Danthu P, Soloviev P, Gaye A et al. 2002. Vegetative propagation of some West African Ficus species by cuttings. Agroforestry Systems 55: 57-63. doi: 10.1023/A:1020254808316

Da Silva MN. 1998. Enraizamento de estacas de seis espécies nativas de mata de galeria: Bauhinia rufa (Bong.) Steud., Calophyllum brasiliense Camb., Copaifera langsdorffii Desf., Inga laurina (Sw.) Willd., Piper arboreum Aubl. e Tibouchina stenocarpa (DC.) Cogn. Embrapa CerradosTese/dissertação (ALICE). Departamento de Botânica, Universidade de Brasília, Brasília.

Deccetti SFC, Paiva R, De Oliveira Paiva PD et al. 2005. La Micropropagation d'Annona Glabra L. à partir de segments nodaux. Fruits 60: 319-325. doi: 10.1051/ fruits:2005038

DíAz J. 2001. Control de erosión en zonas tropicales. Universidad Industrial de Santander, Libreria UIS, Bucaramanga, Colombia.

Dos Santos JdP, Davide AC, Teixeira LAF et al. 2011. Enraizamento de estacas lenhosas de espécies florestais. Cerne 17: 293-301.

Fournet J. 2002. Flore illustrée des phanérogames de Guadeloupe et de Martinique, nouvelle édition revue et augmentée. Cirad, Montpellier, Gondwana Martinique.

Gayot M, Procopio L, Conjard S et al. 2018. Étude de la typologie des ripisylves de Guadeloupe et proposition d'espèces utilisables en génie végétal sur les berges. Office national des forêts, Parc National de Guadeloupe, Guadeloupe.

GeOPORTAIL 2019. Web site. URL: http:// https://www. geoportail.gouv.fr

Grange RI \& LOACH K. 1985. The effect of light on the rooting of leafy cuttings. Scientia Horticulturae 27: 105-111. doi: 10.1016/0304-4238(85)90060-3

Hallé F. 2005. Plaidoyer pour l'arbre. Actes Sud, France.

Hernández RMS, Simón GV \& Arellano-Ostoa G. 1999. Enraizamiento de Estacas de Icaco (Chrysobalanus Icaco L.) Sometidas a Aplicaciones de Auxinas. Bioagro 11: 103-108.

Huc R \& Bariteau M. 1987. Tabebuia heterophylla (DC) Britton; données nouvelles sur la reproduction sexuée et végétative. Annales Des Sciences Forestières 44: 359-364.

Husen A \& PAL M. 2007. Effect of branch position and auxin treatment on clonal propagation of Tectona grandis Linn. f. New Forests 34: 223-233. doi: 10.1007/ s11056-007-9050-y

Jacques A, Carrière EA, Duchartre PES et al HérincQ F \& Naudin C. 1847. Manuel général des plantes arbres et arbustes: comprenant leur origine, description, culture, leur application aux jardins d'agrément, à l'agriculture, aux forêts, aux usages domestiques, aux arts et à l'industrie, et classés selon la méthode de Decandolle. Librairie agricole de Dusacq, Paris.

Janssen P, Cavaillé P, Bray F \& Evette A. 2019. Soil bioengineering techniques enhance riparian habitat quality and multi-taxonomic diversity in the foothills of the Alps and Jura Mountains. Ecological Engineering 133: 1-9. doi: 10.1016/j. ecoleng.2019.04.017 
KonToH IH. 2016. Effect of growth regulators and soil media on the propagation of Voacanga africana stem cuttings. Agroforestry Systems 90: 479-488. doi: 10.1007/s10457-015-9870-2

Leung FTY, Yan WM, Hau BCH, \& Tham LG. 2018. Mechanical pull-out capacity and root reinforcement of four native tree and shrub species on ecological rehabilitation of roadside slopes in Hong Kong. Journal of Tropical Forest Science 30: 25-38. doi: $10.26525 / \mathrm{jtfs} 2018.30 .1 .2538$

Lilin C \& Koohafkan P. 1987.Technique biologique de conservation des sols en Haïti. FAO, Port-au-Prince (Haiti). Ministère de L'Agriculture des Ressources Naturelles et du Développement Rural, Port-au-Prince (Haiti). Centre de Formation en Amenagement des Bassins Versants, Port-au-Prince.

LOACH K \& GAY AP. 1979. The light requirement for propagating hardy ornamental species from leafy cuttings. Scientia Horticulturae 10: 217-230. https:// doi.org/10.1016/0304-4238(79)90077-3

Louppe D, Oteng-Amoako AA \& Martin B. 2008. Ressources végétales de l'Afrique tropicale. Prota 7(1) : bois d'oeuvre. PROTA, Wageningen.

MARTIN FW. 2010. Les clôtures végétales, leur role sur la petite ferme. Echo Technical Note. Florida.

Myers N, Mittermeier RA, Mittermeier CG et al. 2000. Biodiversity hotspots for conservation priorities. Nature 403: 853-858. doi: 10.1038/35002501

Nakamura F \& Inahara S. 2007. Fluvial geomorphic disturbances and life history traits of riparian tree species. Pp. 283-310 In:JOHNSON EA \& MIYANISHI $\mathrm{K}$ (Eds). Plant disturbance ecology: the process and the response. Elsevier. doi: 10.1016/B978-0-12-8188132.00008-3

Noisette L. 1826. Manuel complet du jardinier maraicher, pépiniériste, botaniste, fleuriste et paysagiste. Ed. Rousselon, Paris.

Norris JE, Stokes A, Mickovski B et Al. 2008. Slope stability and erosion control. Springer, Dordrecht.

Pereira DP, Moreira ÉFA, Machado ER et al. 2017. Indolbutiric Acid responses on rooting and survival of Hymenaea courbaril L. cuttings. Revista Brasileira de Tecnologia Aplicada nas Ciências Agrárias 10: 111-117.

Planchon L 1888. Etude sur les produits de la famille des sapotées. Hamelin, Paris.

Polster DF \& Bio MSR. 2016. Natural processes for the restoration of drastically disturbed sites. JASMR, 5: 77-90 doi: 10.21000/JASMR16020077

Howard RA. 1977. Flora of the lesser Antilles Leeward and Windward islands: Pteridophyta. Volume 2. Arnold Arboretum, Harvard University.

Rey F \& Burylo M 2014. Can bioengineering structures made of willow cuttings trap sediment in eroded marly gullies in a Mediterranean mountainous climate? Geomorphology 204: 564-572. doi: 10.1016/j. geomorph.2013.09.003

Rios MNS, Ribeiro JF \& Rezende ME. 2001. Propagação vegetativa: enraizamento em estacas de espécies nativas de Mata de Galeria. Cerrado: caracterização e recuperação de Matas de galeria. Embrapa cerrados, Planaltina.

Rood SB, BraAtne JH \& Hughes FMR. 2003. Ecophysiology of riparian cottonwoods: stream flow dependency, water relations and restoration. Tree Physiology 23: 1113-1124. doi: 10.1093/treephys/23.16.1113

Rousteau A, Portecop J \& Rollet B. 1996. Carte écologique de la Guadeloupe. ONF, UAG, PNG, CGG, Jarry, Guadeloupe.

SAIFuddin M \& Normaniza O. 2016. Rooting characteristics of some tropical plants for slope protection. Journal of Tropical Forest Science 28: 469-478.

Sellers B, Díaz R \& Overholt W. 2008. Control of West Indian marsh grass with glyphosate and imazapyr. Journal of Aquatic Plant Management 46: 189-192.

Schiechtl HM \& Stern R. 1996. Water Bioengineering Techniques for Watercourse, Bank and Shoreline Protection. Blackwell Science, Oxford UK.

Schmitt K, Schäffer M, Koop J \& Symmank L. 2018. River bank stabilization by bioengineering: potentials for ecological diversity. Journal of Applied Water Engineering and Research 6: 262-273. doi: 10.1080/23249676.2018.1466735

Solicaz. 2016. Guyafix: mise en place d'une production de plantes fixatrices d'azote endémiques de Guyane pour la restauration des sites dégradés. DEAL, Guyane.

Teklehaimanot Z, Mwang'ingo PL, Mugasha AG \& Ruffo CK. 2004. Influence of the origin of stem cutting, season of collection and auxin application on the vegetative propagation of African Sandalwood (Osyris lanceolata) in Tanzania. The Southern African Forestry Journal 201: 13-24. doi: 10.1080/20702620.2004.10431770

Thirunavoukkarasu M, Brahmam N \& Dhal K. 2004. Vegetative propagation of Hymenaea courbaril by air layering. Journal of Tropical Forest Science 16: 268-70. doi: 10.1590/1806-908820200000005

TROPICOS 2019. Tropicos.org. Missouri Botanical Garden. http:/ / www.tropicos.org

IUCN 2019. Liste rouge de la flore vasculaire de Guadeloupe. Paris, France.

VESK PA. 2006. Plant size and resprouting ability: trading tolerance and avoidance of damage? Journal of Ecology 94: 1027-1034. doi: 10.1111/j.13652745.2006.01154.x

ZeH H. 2007. Soil Bioengineering Construction Type Manual. European Federation for Soil Bioengineering, Zürich. 